\title{
tolentị

\section{Forecasting Model Selection of Curly Red Chili Price at Retail Level}

\author{
Ketut Sukiyono ${ }^{1}$ and Miftahul Janah ${ }^{2}$ \\ ${ }^{I}$ Department of Agricultural Socio-Economics, Faculty of Agriculture, University of Bengkulu, Indonesia \\ ${ }^{2}$ Department of Magister Agribusiness, Faculty of Agriculture, University of Bengkulu, Indonesia
}

\begin{abstract}
Chilli is one of strategic commodity in Indonesia due to its contribution to inflation level. For this reason, future price information is very importance for designing price policy. Future price merely can be provided by conducting a price forecasting. Various forecasting models can be applied for this purpose; the problem is which the best model for forecasting is. This study aims to select the most accurate forecasting model of curly red chili prices at the retail level. The data used are monthly data, from $2011-2017$. Five forecasting models are applied and estimated including Moving Average, Single Exponential Smoothing, Double Exponential Smoothing, Decomposition, and ARIMA. The best model is selected based on the smallest MAPE, MSE and MAD values. The results show that the most accurate forecasting model is ARIMA $(1,1,9)$.
\end{abstract}

Keywords: curly red chili, forecasting, retail

Received 13 March 2019 | Revised 30 March 2019 | Accepted 31 March 2019

\section{Introduction}

As an important commodity for the Indonesian economy, chili often experiences sharp price increases resulting in a high contribution to inflation. Chili is included in the group of vegetable plants which have sharp price fluctuations. [1] Reported that in the period of 2010-2014, chili prices at a producer level have raised by $17.70 \%$ from IDR 16,343 in 2010 to IDR 19,237 in 2014. Many factors contributed to those phenomena; among them is consumption per capita, the rainy season, Ramadan, and the New Year [2]. In addition, the Central Statistics Agency (BPS) noted that the increase in prices of foodstuffs such as shallots and chilies had an impact on inflation in March 2016 which was $0.19 \%$. Although in the past few periods, chili with other food commodity groups has also contributed to deflation in Indonesia [3].

The uncertainty of chili prices and their impact on the Indonesian economy result in very important information on chili prices in the future. This information can only be provided with a forecasting process and this requires a fitting forecasting method. Forecasting is estimating

\footnotetext{
*Corresponding author at: Department of Agricultural Socio-Economics, Faculty of Agriculture, University of Bengkulu, Jl. WR. Supratman Kandang Limun, Bengkulu, Indonesia

E-mail address: ksukiyono@unib.ac.id, jannahmiftahu1016@gmail.com
} 
something in the future based on previous data that is scientifically analyzed, especially using statistical methods. Forecasting, according to [4] is an activity of a business function that predicts sales and use of products so that products can be made in the right amount. Many forecasting methods can be applied to forecast chili price, such as Moving Average, Exponential Smoothing, Decomposition and ARIMA (Autoregressive Integrated Moving Average). The problem is whether the forecasting model is the most appropriate and accurate with chili price data at the retail level. The choice of this model can be done by estimating all available forecasting models and selecting the best model with the available statistical rules. This method has been used by [5] for rice prices, [6] for coffee prices, and [7] for cocoa prices.

Departing from the discussion above, this study aims to determine the best chili price forecasting model at the best retail level. For this purpose, the MA, Exponential Smoothing, Decomposition, and ARIMA models are estimated and selected using the MAPE, MAD, and MSE indicators.

\section{Methodology}

\subsection{Description of Statistics on Red Chili Prices}

The data used in this study are monthly time series data of the red Chili at the retail level in 2011-2017 (84 observations). Data are obtained from the Central Statistics Agency and the Ministry of Trade.

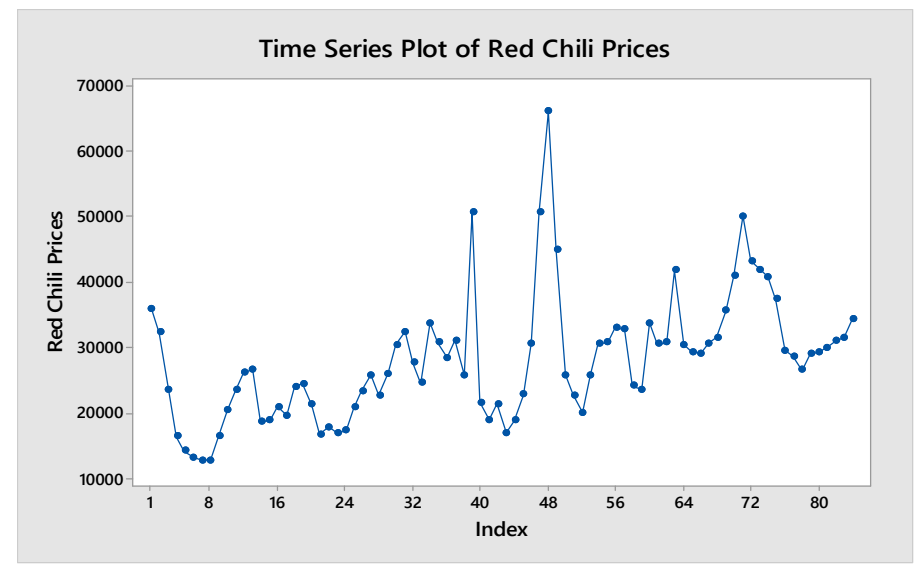

Figure 1. Red Chili Prices Plot

Based on the results of historical data regarding the price of red Chili at the retail level, prices fluctuate and are not stable. The price instability can be recognized by examining Figure 1 where the price trend tends to increase over a certain period of time, namely in December, January, March. In addition, data declined in May, June, July. So that it can be concluded that the price of red Chili undergoes fluctuating changes and has a trend component and seasonal variations. Price increases occur from October to January. According to [5], the appropriate 
method for forecasting price data that has fluctuated in several months is the Decomposition method. However, this judgment should be compared with other models including Moving Average, Exponential Smoothing, and ARIMA.

The following is a summary of statistics from the retail price of red Chili data from January 2011 to December 2017 can be seen in Table 1. Table 1 presents that the average value of red Chili at the retail level from 2011 to 2017 is 27,978 (84 observations), while for data deviations (standard deviation) to the average is 9455 .

Table 1. Descriptive Statistics of Red Chili Prices at Retail Level

\begin{tabular}{ccccc}
\hline & Mean & Standard Deviation & Minimum & Maximum \\
\hline Red Chili Price (IDR) & 27.98 & 9455 & 12.72 & 65.95 \\
\hline
\end{tabular}

\subsection{Model Analysis}

\subsubsection{Simple Moving Average Model}

The Moving Average method uses actual data for new prices to generate forecast values for the future price ([8] and [4]). [9] stated this method is often used on quarterly or monthly data to help observe components of a time series. The greater the order of moving averages will results in the greater effect on the smoothing. Research by [10] [11] are some examples of research that use this model for forecasting silver product demand and stock prices respectively. Statistically, the Moving Average model is given by:

$$
P_{t+1}=\frac{P_{t}+P_{t-1}+P_{t-2}+\ldots+P_{t-N+1}}{N}
$$

where $P_{t+1}$ is the forecasted price for the period $\mathrm{t}+1, P_{t}$ is the price in the period $\mathrm{t}$, and $\mathrm{N}$ is the period of the moving average.

\subsubsection{Exponential Smoothing}

Exponential smoothing methods are the most widely used forecasting methods. This method was initially developed by Robert G. Brown [12] and further developed by [13] for forecasting the inventory control systems. Exponential smoothing is a forecasting method that the observed time series data are weighted unequally. Two types of exponential smoothing models are widely used, i.e., Simple Exponential Smoothing (SES) and Double Exponential Smoothing (DES). SES can be used for time series that contain neither no-trend nor seasonality [14].

Formula Single Exponential Smoothing is:

$$
\hat{P}_{t+1}=\alpha P_{t}+(1-\alpha) \hat{P}_{t}
$$


where $\hat{P}_{t+1}$ is the forecast price at the time $\mathrm{t}+1 ; P_{t}$ is the actual price at $\mathrm{t}$; observed; $\hat{P}_{t}$ is the forecast $P_{t}$; and $0<\alpha<1$ is the smoothing parameter.

[15] explained that Double Exponential Smoothing (DES) computes a trend forecasting equation by applying a special weighting function and emphasizing on the most recent time periods. This forecasting equation will change from period to period. The DES makes use of the following formulas:

$$
\begin{aligned}
& \hat{P}_{t}=\alpha P_{t}+(1-\alpha)\left(\hat{P}_{t-1}+b_{t-1}\right) \\
& b_{t}=\gamma\left(\hat{P}_{t}-\hat{P}_{t-1}\right)+(1-\gamma) b_{t-1} \\
& F_{t+m}=\hat{P}_{t}+b_{t} m
\end{aligned}
$$

Where $\mathrm{m}$ is the number of periods to be predicted; $F_{t+m}$ is forecasting prices in the next $\mathrm{m}$ period; $b_{t}$ is a smoothing trend in period t, and $\alpha$ and $\gamma$ are smoothing parameter.

In the DES method, the most decisive parameters is smoothing constants $\alpha$ and $\gamma$ which are both between 0 and 1 . Furthermore, the trial and error method will be used to select smoothing constants $\alpha$ and $\gamma$ which produce the smallest forecasting error value for both settlement type DES from Brown and Holt.

\subsubsection{Decomposition}

Decomposition methods are used both for short and long term predictions. [16] explains that the decomposition method basically is to decompose series data into several patterns; namely trend, cyclical and seasonal, and identify each of these components separately. This is done, according to Makridakis et al, to help improve forecasting accuracy and help understand better data behaviour. The Decomposition Model has two components namely Additive and Multiplicative which observe in predicting trends, seasonal and forecasting cycles [17] Mathematically, the additive decomposition model can be written as:

$$
P_{t}=T_{t}+S_{t}+C_{t}+I_{t}
$$

Whereas the multiplicative decomposition model can be written:

$$
P_{t}=T_{t} \times S_{t} \times C_{t} \times I_{t}
$$

where $P_{t}$ is red chili price in period $\mathrm{t}$; $T_{t}$ is trend component in period $t ; S_{t}$ is a seasonal component in period $t ; C_{t}$ is a cyclic component in period $t ; I_{t}$ irregular component in period $t$; and $t$ is time period. 


\subsubsection{ARIMA (Autoregressive Integrated Average)}

ARIMA model is applied to forecast a red chili in a response time series as a linear combination of its own past prices and past errors [18]. This model procedure provides a comprehensive set of tools for univariate time series model identification, parameter estimation, and forecasting. Many research applied the ARIMA model to forecast price in the future, such as [19] [20] and [21]. [22] explained that ARIMA is divided into three stages, namely, identifying, estimating/fitting, and forecasting. In addition, according to [23], an ARIMA model is characterized by the notation ARIMA $(p, d, q)$, where $p, d$, and $q$ denote orders of AutoRegression (AR), Integration (differencing) and Moving Average (MA), respectively. Thus, the ARIMA model $(p, d, q)$ is given by:

$$
P_{t}=\alpha_{0}+\left(1+\alpha_{1}\right) P_{t-1}+\ldots+P_{1-q}+\left(1+\alpha_{\rho}\right) P_{t-p}+\theta_{1} e_{t-1}+\theta_{2} e_{t-2}+\ldots+\theta_{q} e_{t-q}
$$

\subsection{Forecasting Accuracy Measures}

There are 3 indicators used for selecting the best forecasting model, namely, Mean Squared Error (MSE); Mean Absolute Deviation (MAD), and Mean Absolute Percentage Error (MAPE). According to [24], the smaller measurement values show more accurate forecasts since it produces minimum forecasting error.

\subsubsection{Mean Squared Error (MSE)}

This MSE value is obtained through the difference between the actual value and the forecasting value squared divided by the number of time series forecasting. The MSE value is used when the residual magnitude is evenly distributed throughout the observation [25].

$$
M S E=\frac{1}{n} \sum_{t=1}^{n}\left(P_{t}-\hat{P}_{t}\right)^{2}
$$

\subsubsection{Mean Absolute Percentage Error (MAPE)}

MAPE is the most useful measure to compare the accuracy of forecasts between different items

or products and commonly used in quantitative methods of forecasting [16]. The MAPE value is used to examine the extent to which the forecasting method is biased.

$$
\begin{aligned}
\text { MAPE } & =\frac{1}{n} \sum_{t=1}^{n} \frac{\left|e_{t}\right|}{P_{t}} \times 100 \% \\
& =\frac{1}{n} \sum_{t=1}^{n} \frac{\left(P_{t}-\hat{P}_{t}\right)}{P_{t}} \times 100 \%
\end{aligned}
$$




\subsubsection{Mean Absolute Deviation (MAD)}

MAD is the average absolute error during a certain period regardless of whether the forecasting results are bigger or smaller than the reality. Mathematically, MAD is formulated as follows: [26]

$$
M A D=\frac{\sum_{t=1}^{n}\left|P_{t}-\hat{P}_{t}\right|}{n}
$$

\section{Results and Discussion}

\subsection{Estimated Forecast Model Results}

\subsubsection{Moving Average Method}

Estimates for the MA model are carried out using price movements starting from order 1 with observations of 84 periods. The model estimation results are presented in Table 2 and Figure 2.

Table 2. Moving Average Model Result

\begin{tabular}{lcccc}
\hline & MA (1) & MA (2) & MA (3) & MA (4) \\
\hline Forecast price (IDR/kg) & 34,269 & 32,841 & 32,192 & 36,124 \\
\hline Accuracy Indicators & & & & \\
\hline a. $\quad$ MAPE & 16 & 20 & 22 & 24 \\
\hline b. $\quad$ MAD & 4637 & 5548 & 6021 & 6457 \\
\hline c. $\quad$ MSD or MSE & $52,437,885$ & $64,724,284$ & $75,317,501$ & $83,245,779$ \\
\hline
\end{tabular}

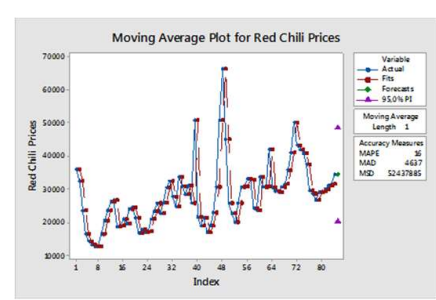

MA(1)

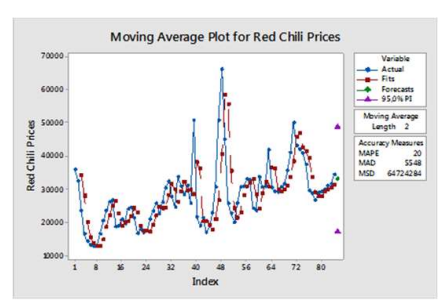

$\operatorname{MA}(2)$

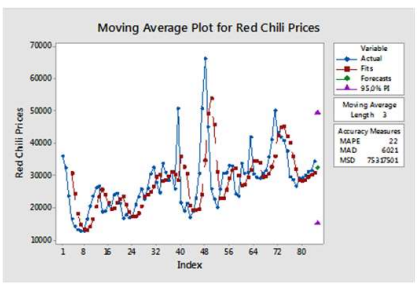

$\operatorname{MA}(3)$

Figure 2. Results of Estimating the Forecast Model with the Moving Average Method

In Table 2 and Figure 2, MA (1) has the smallest MAPE, MAD, and MSE values compared to MA(2), MA(3), and MA(4). These results conclude that MA(1) is the most accurate model for predicting the price of red chili at the retail level in the future. With this model, the next period value of the red chill price is IDR 34,269 .

\subsubsection{Single Exponential Smoothing Method}

The SES method is a forecasting technique developed from simple moving averages [27]. This method is carried out with several levels of $\alpha$, starting from 0.1 to 0.9 . The results of the estimation of the Single Exponential Smoothing method are shown in Table 3. 
Based on Table 3, the smallest value of MAPE, MAD, and MSE is obtained at the value of $\alpha=$ 0.9. Thus, the SES model is $\hat{P}_{t+1}=0.9 P_{t}+0.1 \hat{P}_{t}$ and based on this model, the price of red chili for the next period is equal to IDR 33,977 .

Table 3. Smoothing Parameter Selection for Single Exponential Smoothing Method

\begin{tabular}{cccc}
\hline$\alpha$ & MAPE & MAD & MSE \\
\hline 0.1 & 22 & 5,907 & $69,607,292$ \\
0.2 & 22 & 5,835 & $67,422,931$ \\
0.3 & 21 & 5,678 & $65,454,232$ \\
0.4 & 21 & 5,546 & $62,991,400$ \\
0.5 & 20 & 5,415 & $60,384,169$ \\
0.6 & 19 & 5,282 & $57,977,616$ \\
0.7 & 18 & 5,117 & $56,011,201$ \\
0.8 & 18 & 4,982 & $54,628,498$ \\
0.9 & 17 & 4,861 & $53,912,425$ \\
\hline
\end{tabular}

\subsubsection{Double Exponential Smoothing Method}

The Double Exponential Smoothing (DES) method is a method used when data shows a trend. The working principle of the Double Exponential Smoothing Holt method is to smooth the trend value with parameters from the original data. For the Holt method smooth the trend value with different parameters from the parameters used in the original series. This smoothing parameter of the double exponential smoothing has a value between 0 and 1 , where $0<\alpha<1$.

In Holt's analysis, it is found that the value of $\alpha$ is 0.2 , and the value of $\gamma$ is 0.1 to 0.9 . Table 4 presents the results of the analysis for the Double Exponential Smoothing method with various values of $\gamma$.

Table 4. Smoothing Parameter of $\gamma$ Selection for Double Exponential Smoothing Model with the Value of $\alpha=0.2$

\begin{tabular}{cccc}
\hline$\gamma$ & MAPE & MAD & MSE \\
\hline 0.1 & 24 & 6,231 & $75,067,727$ \\
0.2 & 25 & 6,584 & $83,400,842$ \\
0.3 & 27 & 7,028 & $92,857,308$ \\
0.4 & 29 & 7,555 & $103,617,602$ \\
0.5 & 30 & 8,046 & $114,841,014$ \\
0.6 & 32 & 8,460 & $125,598,529$ \\
0.7 & 34 & 8,898 & $135,960,796$ \\
0.8 & 35 & 9,226 & $146,726,474$ \\
0.9 & 36 & 9,531 & $158,394,417$ \\
\hline
\end{tabular}


The accurate forecasting model is selected from the smallest MAPE, MAD and MSE values. From Table 4, the smallest value of MAPE, MAD, and MSE occurs when $\alpha=0.2$ and $\gamma=0.1$. This DES model has the MAPE, MAD, and MSE value of 24\%, 6, 231 and 75,067,727 respectively.

When DES and SES are compared, the SES is the accurate model for predicting curly red chili prices. This conclusion is based on the value of the three accuracy indicators possessed by the SES model where the SES model has MAPE, MAD and MSE values that are smaller than the DES model as presented in Table 5.

Table 5. Comparison SES and DES Model for Curly Red Chili Price

\begin{tabular}{lcccc}
\hline \multicolumn{1}{c}{ Forecasting Model } & MAPE & MAD & MSE & Conclusion \\
\hline Single Exponential Smoothing (SES) & 17 & 4,861 & $53,912,425$ & SES is the best \\
Double Exponential Smoothing (DES) & 24 & 6,231 & $75,067,727$ & model \\
\hline
\end{tabular}

\subsubsection{Decomposition Method}

The Decomposition Model is a method that identifies separate components of the basic pattern that characterize data, especially time series, economic and business data [16]. The results of this Decomposition method are using both Additive Decomposition and Multiplicative Decomposition. The results of the analysis can be seen in Figure 3.

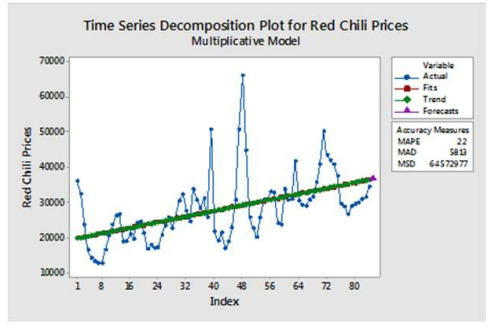

Multiplicative

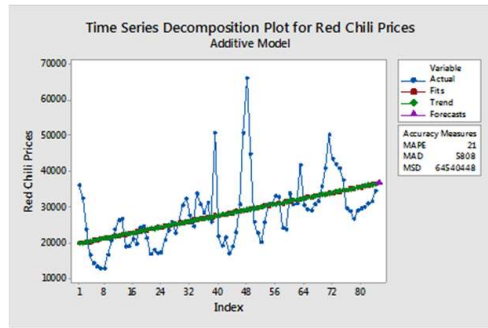

Additive

Figure 3. Results of Estimated Model Prediction with Decomposition Method

Looking at both figures above, the predictive price both for multiplicative and additive decomposition model have relatively similar predictive values, that is, IDR 36.671 and IDR 36.670. This indicates that whether the multiplicative decomposition model or additive decomposition model will give a similar accuracy when it is used to forecast the monthly price of curly red chili at retail price. However, statistically additive decomposition model is more accurate than the multiplicative decomposition model in predicting curly red chili price. This selection is based on the MAPE, MAD and MSE indicator values of the additive decomposition model which is smaller than its counterpart, namely, the multiplicative decomposition model as presented in Table 6 . 
Table 6. Comparison of Multiplicative and Additive Decomposition Methods

\begin{tabular}{lcccc}
\hline \multicolumn{1}{c}{ Decomposition } & MAPE & MAD & MSD & Conclusion \\
\hline Multiplicative & 22 & 5,813 & $64,572,977$ & The additive is the \\
Additive & 21 & 5,808 & $64,540,448$ & accurate model \\
\hline
\end{tabular}

\subsubsection{ARIMA}

Before using the ARIMA model, one of the requirements that must be met is that the data must be stationary. According to [4], time series data are regarded as stationary if the mean and the autocorrelation structures are constant over time. If not stationary, the stochastic trend of the series is eliminated by differencing, while the logarithmic transformation is used to stabilize the variance. Two methods can be used to determine whether the time series data are stationary or not, namely, by considering the graph of ACF (Autocorrelation Function) and PACF (Partial Autocorrelation Function), and applying a unit root test of Augmented Dickey-Fuller.

Figure 4 presents autocorrelation and partial autocorrelation of red chili price data. This figure shows that the formed autocorrelation function is rapidly falling into a sinusoidal pattern while formed partial autocorrelation function also exhibits insignificant.

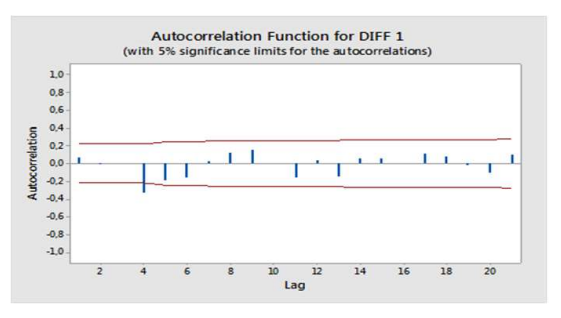

$\mathrm{ACF}$

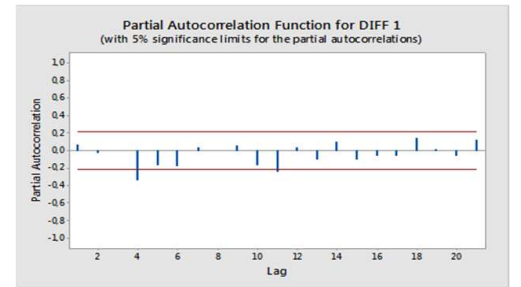

PACF

Figure 4. Auto and Partial Autocorrelation Function for Curly Red Chili

Table 7. present stationary test for curly red chili data. ADF test is -3.71 with a probability value of 0.02 . This test informs that hypothesis of the existence of unit root is accepted, thus, the original time series price of curly red chili is non-stationary. After the first-difference, the ADF test result after the first order difference is -9.27 with the probability value of 0.00 . This concludes that the hypothesis of the existence of unit root should be rejected. This result also informs that the original time series after the first order difference is stationary. Therefore, the value of $d$ is 1 for ARIMA (p,1,q) model of the original time series.

Table 7. Unit Root Test for Stationarity using Augmented Dickey-Fuller

\begin{tabular}{ccccc}
\hline No & Data & t - statistic & Prob $^{*}$ & Conclusion \\
\hline 1 & Original Data & -3.71 & 0.02 & Non-stationary \\
2 & After First Differencing & -9.27 & 0.00 & Stationary \\
\hline
\end{tabular}

${ }^{*}$ [28] one-sided p-value 
After ensuring data stationary, the next step is identifying the level of $p$ and $q$. After comparing all fit statistics, as presented in Table 8 , the best ARIMA model is ARIMA $(1,1,9)$. This selection is based on the lowest value of MAPE, MAD, and MSE. ARIMA $(1,1,9)$ has the MAPE, MAD and MSE value of $14.70 \%, 4,066,461$ and 6,334,551. The ARIMA $(1,1,9)$ model is presented in Table 8 .

Table 8. ARIMA Estimation Results

\begin{tabular}{cccc}
\hline Orde & MAPE & MAD & MSE \\
\hline $1,1,5$ & 15.05 & $4,110,255$ & $6,499,988$ \\
$1,1,6$ & 15.20 & $4,139,229$ & $6,612,798$ \\
$1,1,7$ & 15.27 & $4,218,777$ & $6,786,387$ \\
$1,1,8$ & 15.36 & $4,335,571$ & $6,884,533$ \\
$1,1,9$ & 14.70 & $4,066,461$ & $6,334,551$ \\
$2,1,1$ & 15.49 & $4,194,841$ & $6,649,005$ \\
$2,1,2$ & 15.98 & $4,304,786$ & $6,778,801$ \\
$2,1,3$ & 15.74 & $4,248,225$ & $6,778,371$ \\
$2,1,4$ & 15.32 & $4,177,631$ & $6,756,981$ \\
\hline
\end{tabular}

Table 9. Estimated Model Parameters of Red Chili Prices

\begin{tabular}{ccccc}
\hline Data & Coefficient & SE-Coefficient & t-statistic & Probability \\
\hline AR (1) & -0.26 & 0.51 & -0.50 & 0.62 \\
MA (1) & 0.15 & 21.65 & 0.01 & 1.00 \\
MA (2) & 0.40 & 18.49 & 0.02 & 0.98 \\
MA (3) & 0.39 & 9.81 & 0.04 & 0.97 \\
MA (4) & 0.42 & 1.28 & 0.33 & 0.74 \\
MA (5) & 0.09 & 7.96 & 0.01 & 0.99 \\
MA (6) & 0.11 & 9.91 & 0.01 & 0.99 \\
MA (7) & 0.06 & 12.35 & 0.01 & 1.00 \\
MA (8) & -0.30 & 13.76 & -0.02 & 0.98 \\
MA (9) & -0.33 & 7.18 & -0.05 & 0.96 \\
\hline
\end{tabular}

\subsection{Selection of the Best Method}

The selection of the best method is made by comparing the values of MAPE, MSD, and MAD from every model that has been estimated before. The following table is the results of the comparison used to determine the best model selection. From Table 10, the most accurate model for forecasting curly red chili prices is $\operatorname{ARIMA}(1,1,9)$. This model has the lowest value of MAPE, MSD, and MAD compared to other alternative forecasting models. This findings is similar to [5] [6] and [7] in which ARIMA is the bests forecasting model for rice prices, coffee prices and cacao prices respectively. The difference is only at the order level of ARIMA and this is quite reasonable because each commodity has a different price behavior. 
Table 10. Comparison of Inter-Model Goodness Criteria

\begin{tabular}{llcc}
\hline \multicolumn{1}{c}{ Forecasting Model } & MAPE & MAD & MSE \\
\hline MA (1) & 16 & 4,637 & $52,437,885$ \\
Single Exponential Smoothing & 17 & 4,861 & $53,912,425$ \\
Double Exponential Smoothing & 24 & 6,231 & $75,067,727$ \\
Additive Decomposition & 21 & 5,808 & $64,540,448$ \\
Multiplicative Decomposition & 22 & 5,813 & $64,572,977$ \\
ARIMA(1,1,9) & 14 & 4,066 & $6,334,551$ \\
\hline
\end{tabular}

\section{Conclusion}

This study is aimed mainly to determine the most accurate forecasting model for curly red chili prices at the retail level. Four alternative forecasting models are proposed and estimated, namely moving average, decomposition, exponential smoothing, and ARIMA. The selection of the most accurate forecasting model is based on the lowest value of MAPE, MAD, as well as MSD. It is concluded that the most accurate model is ARIMA $(1,1,9)$ by most of the accuracy measures.

\section{REFERENCES}

[1] Kementerian Pertanian, "Outlook cabai merah", Pusat Data dan Informasi Pertanian. Kementerian Pertanian. Jakarta, 2016.

[2] M. Farid and N. A. Subekti, "Tinjauan terhadap produksi, konsumsi, distribusi dan dinamika harga cabe di Indonesia," Buletin Ilmiah Litbang Perdagangan, vol. 6, no. 2, pp. 211-233, $2012 . \quad$ [Online].

Available: http://jurnal.kemendag.go.id/index.php/bilp/article/view/132.

[3] Bank Indonesia, "Inflasi Juni 2018 Terjaga Didukung Harga Pangan yang Terkendali," $2018 . \quad$ [Online] Available: https://www.bi.go.id/id/moneter/...inflasi/.../Analisis\%20Inflasi\%20-\%20Juni18.pdf

[4] V. Gaspersz, Production Planning and Inventory Control. Jakarta: Gramedia Pustaka Utama, 2005.

[5] K. Sukiyono and Rosdiana, "Pendugaan model peramalan harga beras pada tingkat grosir," AGRISEP, vol. 17, no. 1, pp. 23-30, 2018. [Online] Available: https://ejournal.unib.ac.id/index.php/agrisep/article/view/4503

[6] Novanda, R. Rizki., E. Sumartono, P. S. Asriani, E. Yuliarti, K. Sukiyono, B. S. Priyono, Irnad, Reswita, M. Suryanty, and V. Octalia, "A comparison of various forecasting techniques for coffee prices," Journal of Physics: Conference Series. 1114, 2018. [Online] Available: https://iopscience.iop.org/article/10.1088/1742-6596/1114/1/012119/pdf.

[7] K. Sukiyono, M. Nabiu, B. Sumantri, R. R. Novanda, N. N. Arianti, Sriyoto, M. Z. Yuliarso, R. Badrudin, M. M. Romdhon, and H. Mustamam, "Selecting an accurate cacao price forecasting model," Journal of Physics: Conference Series. 1114, 2018. [Online] Available: https://iopscience.iop.org/article/10.1088/1742-6596/1114/1/012116/pdf .

[8] E. Padang, G. Tarigan, and U. Sinulingga, "Peramalan Jumlah Penumpang Kereta Api Medan-Rantau Prapat dengan Metode Pemulusan Eksponensial Holt-Winters," Saintia Matematika, vol. 2, pp. 161-174, 2013. [Online] Available: https://media.neliti.com/media/publications/221287-peramalan-jumlah-penumpang-keretaapi-me.pdf.

[9] W. L. Winston, Operation Research: Application and Algorithm. 4th Ed, Thomson Brooks/Cole, 2004. 
[10] Yuniastari, N. L. A. Kartika, and I. G. P. W. W. Wirawan, "Peramalan permintaan produk perak menggunakan metode simple moving average dan exponential smoothing," Jurnal Sistem dan Informatika, vol. 9, no. 1, pp. 97-106, 2004. [Online] Available: https://jsi.stikom-bali.ac.id/index.php/jsi/article/view/41.

[11] Siregar, A. Ruben, and E. Riksakomara, "Pembangunan aplikasi berbasis webuntuk peramalan harga saham dengan metode moving average, exponential smoothing, dan artificial neural network," Jurnal Teknik ITS, vol. 5, no. 2, pp. 347-352, 2016. [Online] Available: http://ejurnal.its.ac.id/index.php/teknik/article/view/17070/2927

[12] S. I. Gass and C. M. Harris, (Eds.). Encyclopedia of Operations Research and Management Science (Centennial edition), Dordrecht, The Netherlands: Kluwer, 2000.

[13] Noeryanti, E. Oktafiani, and F. Andriyani, "Aplikasi pemulusan eksponensial dari brown dan dari holt untuk data yang memuat trend," Prosiding Seminar Nasional Aplikasi Sains dan Teknologi (SNAST) Periode III, pp. 447-455, 2012. [Online] Available: repository.akprind.ac.id/sites/files/.../2012/noeryanti_15454.pdf

[14] Ruiter, Michelle de, "Using exponential smoothing methods for modelling and forecasting short-term electricity demand," Erasmus School of Economics Bachelor Econometrics and Operations Research, 2017. [Online] Available: http://hdl.handle.net/2105/38564

[15] C. C. Holt, Forecasting Trends and Seasonals by Exponentially Weighted Averages, O. N. R. Memorandum 52/1957, Carnegie Institute of Technology, 1957.

[16] S. Makridakis, S. C. Wheelwright, and R. J. Hyndman, Forecasting Methods and Applications. New York: Wiley, 1998. [Online] Available:

www.forecastingprinciples.com/files/MakridakisbyFaria.pdf

[17] O. Kendek, J. J. D. Prang, and M. Paendong, "Prediksi jumlah pengunjung perpustakaan universitas sam ratulangi manado menggunakan metode dekomposisi," $J d C$, vol. 3, no. 1, pp. 73-80, 2014. [Online] Available: https://ejournal.unsrat.ac.id/index.php/decartesian/article/view/4000

[18] E. Weiss, "Forecasting commodity prices using ARIMA," Technical Analysis of Stocks \& Commodities, vol. 18, no. 1, pp. 18-19, 2000.

[19] Q. Zhang, B. D. Wang, B. He, Y. Peng, and M. L. Ren, "Singular spectrum analysis and arima hybrid model for annual runoff forecasting," Water Resources Management, vol. 25, no. 11, pp. 2683-2703, $2011 . \quad$ [Online] Available:https://link.springer.com/article/10.1007/s11269-011-9833-y.

[20] W. C. Juang, S. J. Huang, F. D. Huang, P. W. Cheng, and S. R. Wann, “Application of time series analysis in modelling and forecasting emergency department visits in a medical centre in southern Taiwan," BMJ Open, vol. 7, pp. 1-7, 2017. [Online] Available:

https://www.ncbi.nlm.nih.gov/pubmed/29196487.

[21] R. Anokye, E. Acheampong, I. Owusu, and E. I. Obang, "Time series analysis of malaria in Kumasi: Using ARIMA models to forecast future incidence," Cogent social sciences, vol. 4, no. 1, pp. 1-13, 2018. [Online] Available: https://www.tandfonline.com/doi/abs/10.1080/23311886.2018.1461544.

[22] G. E. P. Box, and G. M. Jenkins, Time Series Analysis: Forecasting and Control. Revised Edition, San Francisco: Holden-Day, 1976.

[23] M. Ekananda, Analisis Data Time Series. Jakarta: Mitra Wacana Media, 2014.

[24] R. Karim, A. Awala, and M. Akher, "Forecasting of wheat production in Bangladesh," Bangladesh J. Agric. Res., vol. 35, no. 1, pp. 17-28, 2010. [Online] Available:

https://www.banglajol.info/index.php/BJAR/article/view/5863/4598.

[25] J. Jarett, Business Forecasting Methods. Cambridge, MA: Basil Blackwell, 1991.

[26] A. H. Nasution and Prasetyawan, Perencanaan dan Pengendalian Produksi. Yogyakarta: Graha Ilmu, 2008. 
[27] R. Biri, Y. A. R. Langi, and M. S. Paedong, "Penggunaan metode smoothing eksponensial dalam meramalkan pergerakan inflasi Kota Palu," Jurnal Ilmiah Sains, vol. 13, no. 1, pp. 68-73 2013. [Online]

Available: https://ejournal.unsrat.ac.id/index.php/JIS/article/viewFile/2035/1621.

[28] J. G. MacKinnon, "Numerical distribution functions for unit root and cointegration tests," Journal of Applied Econometrics, vol. 11, pp. 601-61, 1996. [Online] Available: https://doi.org/10.1002/(SICI)1099-1255(199611)11:6<601::AID-JAE417>3.0.CO;2- 